\title{
Spectrophotometric Determination of Trace Amount of Nickel(II) in Tea Leaves Sample by Using Antipyriyl azo-2,7-naphthalendiol as New Reagent
}

\author{
MASAR A. AWAD and HUSSAIN.J.MOHAMMED* \\ Chemistry Department, Faculty of Science, Kufa University, Iraq \\ ibrahiem_af@yahoo.com
}

Received 23 April 2013 / Accepted 20 May 2013

\begin{abstract}
A new, simple, sensitive and rapid spectrophotometric method is proposed for the determination of trace amount of nickel(II). The method is based on the formation of a 1:2 complex with 1-(4'- pyrazolon azo) 2,7-naphthalendiol (1-APANDOL) as a new reagent is developed. The complex has a maximum absorption at $514 \mathrm{~nm}$ and $\varepsilon_{\max }$ of $2.0 \times 10^{4} \mathrm{~L} \mathrm{~mol}^{-1} \mathrm{~cm}^{-1}$. A linear correlation (0.1-2.0 $\mu \mathrm{g} \mathrm{mL}^{-1}$ ) was found between absorbance at $\lambda_{\max }$ and concentration. The accuracy and reproducibility of the determination method for various known amounts of nickel(II) were tested. The results obtained are both precise (RSD was better than $0.63 \%$ ) and accurate (relative error was better than $0.2 \%$ ). The effect of diverse ions on the determination of nickel(II) to investigate the selectivity of the method were also studied. The stability constant of the product was $0.13 \times 10^{8} \mathrm{~L} \mathrm{~mol}^{-1}$. The proposed method was successfully applied to the analysis of synthetic mixtures and tea sample without any preliminary concentration or separation.
\end{abstract}

Keyword: Nickel(II) determination, Spectrophotometry, Antipyriyl azo 2,7-naphthalendiol, Tea leaves

\section{Introduction}

Azo compounds have a great industrial importance ${ }^{1}$ as well as biological activity ${ }^{2-4}$. They can also be used in subtractive photographic process and color pictures ${ }^{5}$ nickel is a nutritionally essential metal and widely distributed in nature ${ }^{6}$. In chemical analysis, metal chelation followed by solvent extraction and spectrophotometric detection is the preferred mode of analysis for a number of metal ions ${ }^{7-9}$. Due to its rapidity, simplicity and wide applications, pyrazolon azo forms colored water insoluble complexes with a large number of metal ions ${ }^{10}$ At present, a lot of analytical methods have been proposed for the determination of nickel(II), including, inductively coupled plasma mass spectrometry (ICP - MS) ${ }^{11}$, atomic absorption spectrometry (AAS) $)^{12}$, solid-phase extraction ${ }^{13}$ and X-ray fluorescence spectrometry ${ }^{14}$ show good sensitivity but is limited because of expensive instrumentation and high cost for routine analysis. According to the best of our knowledge, this reagent has not been reported in the literature as being used for any cation determination. In this study, we wish to report this reagent as a selective reagent in spectrophotometric determination of trace amounts of nickel(II). 


\section{Experimental}

The reagent was prepared by coupling 2,7-naphthalendiol with diazotate 4-amino antipyrine in alkaline alcoholic solution. A diazonium solution was prepared by taking $1 \mathrm{~g} 4$-amino antipyrine in $25 \mathrm{~mL}$ of ethanol and concentrated hydrochloric acid with $5 \mathrm{~mL}$ of distilled water and adding sodium nitrite solution drop wise at $0-5{ }^{\circ}$ C. $2,7-$ Naphthalendiol $1.1 \mathrm{~g}$ was dissolved in $20 \mathrm{~mL}$ of ethanol and $30 \mathrm{~mL}$ of $0.1 \mathrm{M}$ sodium hydroxide were added at $0-5{ }^{\circ} \mathrm{C}$. The mixture was left to stand over night. The precipitate was filtered off and recrystallized from ethanol ${ }^{15}$ (Scheme 1).<smiles>Cc1c(N=[W])c(=O)n(C)n1C</smiles>

Scheme 1. Preparation of reagent (1-APANDOL)

\section{Preparation of nickel(II)complex}

The complex was prepared by direct reaction between nickel chloride hexahydrate and the appropriate ligand (1-APANDOL) in 1:2 mole ratio, using aqueous ethanol as solvent. The formed precipitate was filtered off, washed with warm ethanol, then dried in a vacuum desiccator.

\section{Apparatus}

Spectrophotometric measurement was made with Shimadzu UV-Visible - 1700 double beam spectrophotometer using $1.00 \mathrm{~cm}$ glass cells. Vibrational spectra were recorded on test scan Shimadzu FT.IR 8000 series. Measurements of pH were made using Hanna, HI9811-5 pHmeter equipped with a glass - saturated calomel combined electrode. Melting points of both ligand and complex were obtained with an electrothermal melting point apparatus. Conductivity was measured in DMSO $\left(1 \times 10^{-3}\right)$ solution with an Alpha digital conductivity model-800. Elemental analysis (C.H.N) were carried out with a EuroEA Elemental Analyser.

\section{Reagents}

All chemicals used were of analytical grades

Nickel(II) stock solution (100 $\mu \mathrm{g} \mathrm{mL}^{-1}$ )

This solution was prepared by dissolving $0.081 \mathrm{~g}$ of nickel chloride hexahydrate in $200 \mathrm{~mL}$ of distilled water, working standard of $\mathrm{Ni}$ (II) solutions were prepared by simple dilution of the appropriate volume of the standard $\mathrm{Ni}(\mathrm{II})$ solution $\left(100 \mu \mathrm{g} \mathrm{mL}^{-1}\right)$ with distilled water. 


\section{1-(4- Antipyriyl azo) 2,7-naphthalendiol ( $1 \mathrm{mM}$ )}

$0.0476 \mathrm{~g}$ of Reagent was dissolved in $250 \mathrm{~mL}$ of ethanol.

\section{Foreign ion solutions $\left(10 \mu \mathrm{g} \mathrm{m}^{-1}\right)$}

All the solutions were prepared by dissolving an appropriate amount of the compound in distilled water in a volumetric flask.

\section{General procedure}

An aliquot of sample containing 1-20 $\mu \mathrm{g}$ of Ni(II) was transfer into a series of $10 \mathrm{~mL}$ standard flask. $2 \mathrm{~mL}$ of $1 \mathrm{Mm}$ of 1-APANDOL was added and $\mathrm{pH}$ was adjusted to 9. The complexes formed were solubilized in water and diluted up to $10 \mathrm{~mL}$ in a standard flask. The absorbance of the resulting solution was measured at the respective absorption maxima against a reagent blank prepared under similar condition.

\section{Results and Discussion}

\section{Properties of (1-APANDOL) and its metal chelate}

1-APANDOL is a tridentate with coordination of azo group nitrogen, hydroxyl group and carbonyl group; it has the following structure.<smiles>Cc1c(/N=N\c2c(O)ccc3ccc(O)cc23)c(=O)n(-c2ccccc2)n1C</smiles>

1-(4-antipyriylazo) 2,7-naphthalendiol

\section{Structure of 1-APANDOL}

Owing to the large conjugated system, the compound showed excellent chelating ability to form inner metal chelates. 1-APANDOL and its metal chelates can be easily solubilized in an aqueous solution. Elemental analyses were carried out on the resulting compound $(\mathrm{C} \%$ calc. 67.37; found 68.16, $\mathrm{H} \%$ calc.4.85; found 5.75, N\% calc.14.96; found 15.34). m.p. $234{ }^{\circ} \mathrm{C}$.

\section{Spectra}

The result of this investigation indicated that the reaction between Ni(II) and 1-APANDOL at $\mathrm{pH} 9$ yield highly soluble coloured product which can be utilized as a suitable assay procedure for $\mathrm{Ni}(\mathrm{II})$. This coloured product has a maximum absorption at $514 \mathrm{~nm}$, the blank at this wave length shows zero absorbance (Figure 1), was adopted in all subsequent experiments. The effect of various parameters on the absorbance intensity of the formed products was studied and the reaction conditions were optimized.

\section{Effect of $p H$}

The electronic absorption of 1- APANDOL and its complex in ethanol have been recorded in the wavelength range 190-800 $\mathrm{nm}$ (Figure 1). The electronic absorption of complex 
showed a red shift for $\left(\pi-\pi^{*}\right)$ electronic transition band. [Ni (L) $)_{2}$ shows one broad in visible region at $(16000-21000) \mathrm{cm}^{-1}$ refer to $\left({ }^{3} \mathrm{~A}_{2 \mathrm{~g}}(\mathrm{~F}) \rightarrow \mathrm{T}_{2 \mathrm{~g}}(\mathrm{~F})\left[\mathrm{v}_{1}\right], \quad{ }^{3} \mathrm{~A}_{2 \mathrm{~g}}(\mathrm{~F}) \rightarrow{ }^{3} \mathrm{~T}_{1 \mathrm{~g}}(\mathrm{~F})\left[\mathrm{v}_{2}\right]\right.$, $\left.{ }^{3} \mathrm{~A}_{2 \mathrm{~g}}(\mathrm{~F}) \rightarrow \mathrm{T}_{1 \mathrm{~g}}(\mathrm{P})\left[v_{3}\right]\right)$ that is in accordance with octahedral geometry of nickel metal ion ${ }^{16,17}$. The $\mathrm{pH}$ of metal complex solutions was adjusted using dilute solutions of $(0.05 \mathrm{M}) \mathrm{NaOH}$ and $(0.05 \mathrm{M}) \mathrm{HCl}$ and the effect on absorbance was studied (Figure 2). The absorbance of the complex was maximum and constant in the $\mathrm{pH}$ range given in Table 1 .

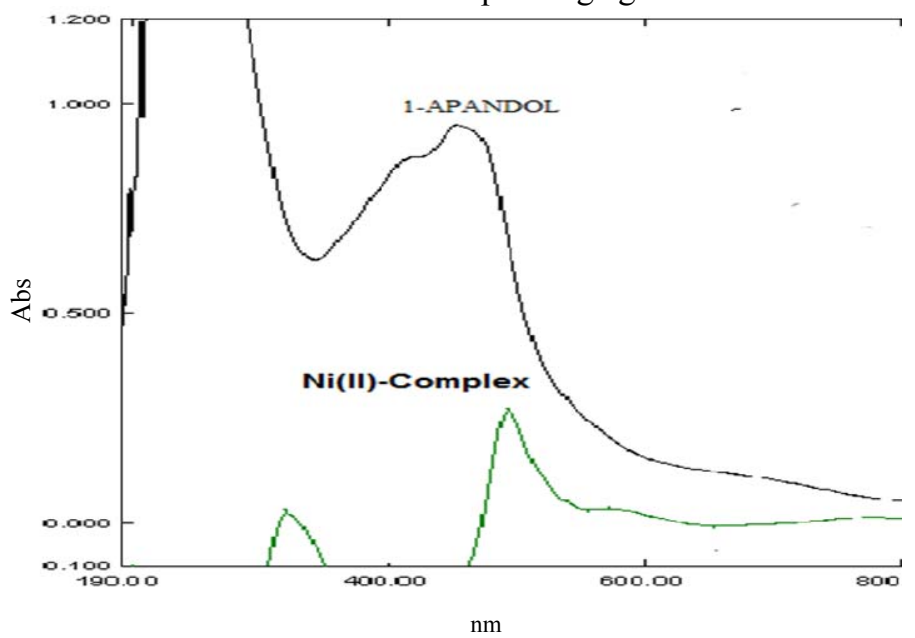

Figure 1. Absorption spectra of $20 \mu \mathrm{g} \mathrm{Ni(II)} \mathrm{treated} \mathrm{as} \mathrm{described} \mathrm{under} \mathrm{procedure} \mathrm{and} \mathrm{measured}$ against reagent blank and 1-APANDOL the reagent blank measured against ethanol.

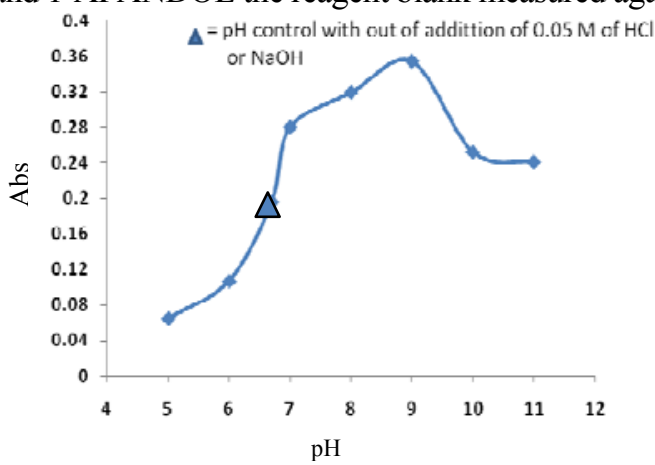

Figure 2. Effect of $\mathrm{pH}$

Table 1. Analytical characteristics of Ni(II) - complex

\begin{tabular}{lc}
\hline \multicolumn{1}{c}{ Characteristic } & Ni(II) -complex \\
\hline Absorption maximum, $\mathrm{nm}$ & 514 \\
Beer s law range, ppm & $0.1-2.0$ \\
pH range & $7-9$ \\
Sandell's sensitivity $\mu \mathrm{g} . \mathrm{cm}^{-2}$ & 0.0029 \\
Molar absorptivity $\left(\mathrm{L} . \mathrm{mol}^{-1} \cdot \mathrm{cm}^{-1}\right)$ & $2.0 \times 10^{4}$ \\
Stability constant $\left(\mathrm{L} . \mathrm{mol}^{-1}\right)$ & $0.13 \times 10^{8}$ \\
Melting point for reagent & $232-234{ }^{0} \mathrm{C}$ \\
Melting point for Ni(II) - complex & $288-290{ }^{0} \mathrm{C}$ \\
\hline
\end{tabular}




\section{Effect of 1-APANDOL concentration}

When various concentrations of of 1-(4'- antipyriylazo) 2,7-naphthalendiol was added to a fixed concentration of $\mathrm{Ni}(\mathrm{II}), 2 \mathrm{~mL}$ of $1 \mathrm{mM}$ 1-APANDOL solution was sufficient to develop the colour to its full intensity and gave minimum blank value, above $2 \mathrm{~mL}$, the absorbance of the blank value was increased causing a decrease in the absorbance of the sample. Therefore, $2 \mathrm{~mL}$ of $1 \mathrm{mM}$ of 1-(4'- antipyriylazo) 2,7-naphthalendiol was used in all subsequent experiments (Figure 3).

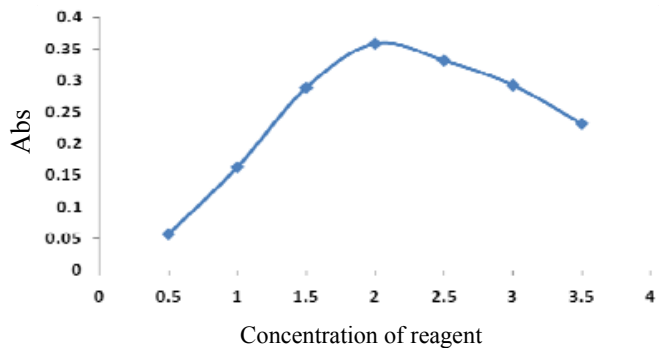

Figure 3. Effect of 1-APANDOL concentration

\section{Effect of reaction time}

The colour intensity reached a maximum after the $\mathrm{Ni}(\mathrm{II})$ has been reacted immediately with 1-APANDOL and became stable after one minute, therefore one minute development time was selected as optimum in the general procedure. The colour obtained was stable for at least $24 \mathrm{~h}$ (Figure 4).

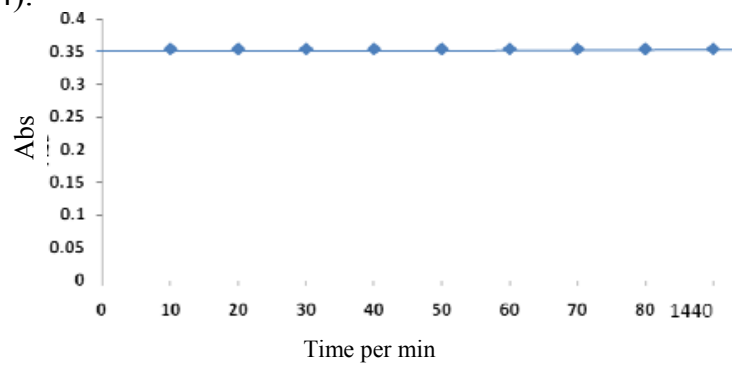

Figure 4. Effect of time on complex of Ni[1-APANDOL $]_{2}$

\section{Effect of temperature}

The effect of temperature on the colour intensity of the product was studied. In practice, the same absorbance was obtained when the colour was developed at room temperature $\left(20-40^{\circ} \mathrm{C}\right)$, but when the volumetric flask were placed in a water-bath at $50-70{ }^{\circ} \mathrm{C}$ a loss in colour intensity and stability were observed, therefore it is recommended that the colour reaction should be carried out at room temperature for complex (Figure 5).

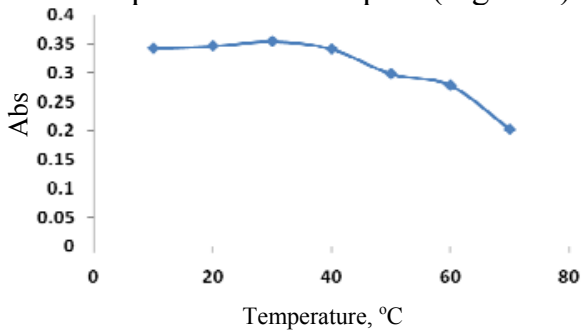

Figure 5. Effect of temperatures on complex Ni[1-APANDOL $]_{2}$ 


\section{Calibration graph}

The calibration equation for $(0.1-2.0 \mu \mathrm{g}$ per $\mathrm{mL}) \mathrm{Ni}(\mathrm{II})$ is $\mathrm{Y}=0.347 \mathrm{x}+0.0009\left(\mathrm{R}^{2}=\right.$ 0.9962). Since the coloured complex is stable for $24 \mathrm{~h}$, the method can be applied to large series of samples. The molar absorptivity and Sandell' sensitivity are given in Table 1 .

\section{Composition of the complex}

The composition of complex was studied in the excess of reagent solution by the mole-ratio and Job s methods (Figure 6,7). A break at a 1:2 (M:L) mole ratio suggested the formation of complex where $\mathrm{M}=\mathrm{Ni}(\mathrm{II})$ and $\mathrm{L}=(1-\mathrm{APANDOL})$.

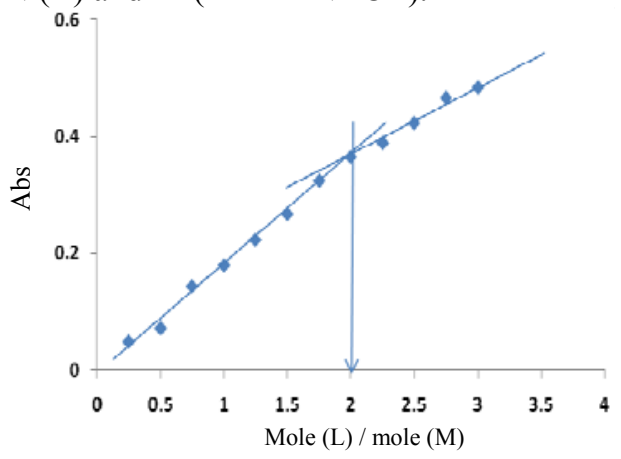

Figure 6. Mole-ratio method for Ni[1-APANDOL $]_{2}$ complex

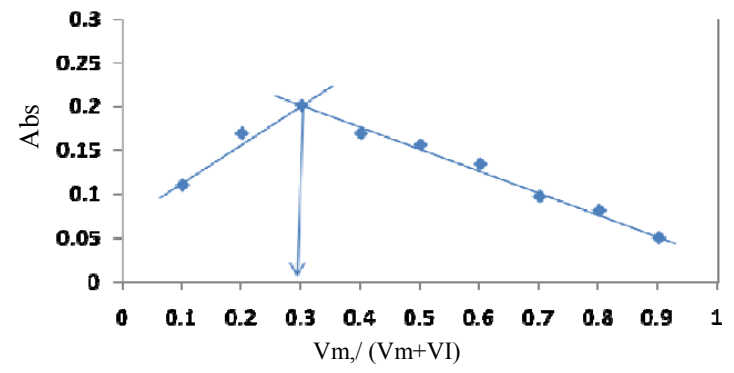

Figure 7. Job s method for Ni[1-APANDOl $]_{2}$ complex

\section{Conductivity measurements}

The solubility of the complexes in dimethy sulfoxide and ethanol permitted of the molar conductivity of $1 \times 10^{-3} \mathrm{M}$ solution at $25^{\circ} \mathrm{C}$ and by comparison, the electrolytic nature for complexes. The low values of the molar conductance data listed in Table 2 indicate that the complexes are non electrolytes.

Table 2. Conductivity values of complex

\begin{tabular}{ccc}
\hline Complex & $\begin{array}{c}\text { Molar conductivity, } \\
\mathrm{S} \mathrm{mole}^{-1} \mathrm{~cm}^{2} \text { (DMSO) }\end{array}$ & $\begin{array}{c}\text { Molar conductivity, } \\
\mathrm{S} \mathrm{mole}^{-1} \mathrm{~cm}^{2},(\text { Methanol) }\end{array}$ \\
\hline $\mathrm{Ni}(1-\mathrm{APANDOL})_{2}$ & 9.7 & 12.4 \\
\hline
\end{tabular}

\section{Interferences}

The effect of diverse ions in the determination metal ion was studied. The metal ion can be determined in the presence of a 5 or more fold excess of cation and anion (Table 3 ). In the experiment, a certain amount of standard $\mathrm{Ni}$ (II) solution, coexisting ion solution and masking 
agent (or absence of masking agent) were added. It is found that all the studied ions interfere seriously. However, their interferences are masked efficiently by addition $1.0 \mathrm{~mL}$ of $0.1 \mathrm{M}$ of $\left(\mathrm{NaNO}_{2}\right)$.

Table 3. Effect of foreign ions

\begin{tabular}{|c|c|c|c|c|}
\hline Foreign ion & M. F. of ion & Conc., & Abs & Error \% \\
\hline $\mathrm{Zn}^{2+}$ & $\mathrm{ZnCl}_{2}$ & 10 & 0.610 & +41.96 \\
\hline $\mathrm{Mn}^{2+}$ & $\mathrm{MnCl}_{2}$ & 10 & 0.505 & +29.9 \\
\hline $\mathrm{Co}^{2+}$ & $\mathrm{CoCl}_{2} \cdot 6 \mathrm{H}_{2} \mathrm{O}$ & 10 & 0.411 & +16.1 \\
\hline $\mathrm{Pb}^{2+}$ & $\mathrm{pbCl}_{2}$ & 10 & 0.401 & +11.72 \\
\hline $\mathrm{Cu}^{2+}$ & $\mathrm{CuCl}_{2} \cdot 2 \mathrm{H}_{2} \mathrm{O}$ & 10 & 0.543 & +34.8 \\
\hline $\mathrm{Fe}^{3+}$ & $\mathrm{FeCl}_{3}$ & 10 & 0.487 & +27.31 \\
\hline $\mathrm{Hg}^{2+}$ & $\mathrm{HgCl}_{2}$ & 10 & 0.441 & +19.72 \\
\hline $\mathrm{Pd}^{2+}$ & $\mathrm{PdCl}_{2}$ & 10 & 0.566 & +37.45 \\
\hline $\mathrm{S}_{2} \mathrm{O}_{8}{ }^{2-}$ & $\mathrm{NaS}_{2} \mathrm{O}_{8}$ & 10 & 0.357 & +0.84 \\
\hline $\mathrm{I}^{-1}$ & KI & 10 & 0.437 & +18.99 \\
\hline $\mathrm{Br}^{-}$ & $\mathrm{NaBr}$ & 10 & 0.383 & +7.57 \\
\hline $\mathrm{SO}_{4}{ }^{2-}$ & $\mathrm{Na}_{2} \mathrm{SO}_{4}$ & 10 & 0.345 & -2.6 \\
\hline $\mathrm{Cl}^{-}$ & $\mathrm{KCl}$ & 10 & 0.425 & +16.7 \\
\hline $\mathrm{CO}_{3}{ }^{2-}$ & $\mathrm{Na}_{2} \mathrm{CO}_{3}$ & 10 & 0.420 & +15.71 \\
\hline $\mathrm{F}^{-}$ & $\mathrm{NaF}$ & 10 & 0.343 & -3.2 \\
\hline
\end{tabular}

FT IR of reagent and its complex

The FT IR of the free ligand and its metal chelate were carried out in the $400-4000 \mathrm{~cm}^{-1}$ Range. The IR bands of the 1-APANDOL and its Ni(II) complex with their probable assignment are given in Table 4. The IR spectrum of ligand shows a broad band at $3414 \mathrm{~cm}^{-1}$, which can be attributed to the phenolic $\mathrm{OH}$ group. However, the $v(\mathrm{~N}=\mathrm{N})$ stretching band in the free ligand is observed at $1494 \mathrm{~cm}^{-1}$. This band is shifted to lower with low intensity at $1454 \mathrm{~cm}^{-1}$ frequency value upon complexation suggesting chelation via the $(\mathrm{M}-\mathrm{N})^{18}$. The IR spectrum of the ligand revealed a sharp band at $1637 \mathrm{~cm}^{-1}$ due to $v(\mathrm{C}=\mathrm{O})$ of pyrazole azo. This band is shifted to lower with low intensity upon complexation ${ }^{19}$. The bonding of oxygen to the metal ion is provided by the occurrence of band at $509 \mathrm{~cm}^{-1}$ as the result of $v(\mathrm{M}-\mathrm{O})^{20,21}$.

Table 4. Selected FT IR data of 1-APANDOL and its complex with Ni(II)

\begin{tabular}{ccccccc}
\hline Compound & $v(\mathrm{OH})$ & $v(\mathrm{C}-\mathrm{H})$ arom. & $v(\mathrm{~N}=\mathrm{N})$ & $v(\mathrm{C}=\mathrm{O})$ & $v(\mathrm{M}-\mathrm{O})$ & $v(\mathrm{M}-\mathrm{N})$ \\
\hline $\mathrm{HL}$ & $3494 \mathrm{~m}$ & $3069 \mathrm{w}$ & $1494 \mathrm{~m}$ & $1637 \mathrm{~s}$ & & \\
{$[\mathrm{Ni}(\mathrm{L})]$} & $3383 \mathrm{~b}$ & $3068 \mathrm{w}$ & $1454 \mathrm{~m}$ & $1612 \mathrm{~m}$ & $509 \mathrm{w}$ & $45 \overline{5} \mathrm{w}$ \\
\hline
\end{tabular}

S: sharp; m: medium; w: weak; b: broad

On the basis of the FT IR, stoichiometric and elemental analysis molar conductivity data the structure of complex can be suggested as the following:-.

\section{Applications}

\section{Determination of nickel(II) in practical samples}

To determine the accuracy and precision of the method, nickel(II) was determined at two different concentrations with different interferences ions and masked these ions by using masking reagent. The results are shown in Table 5, indicate that satisfactory precision and accuracy could be attained with proposed method. 


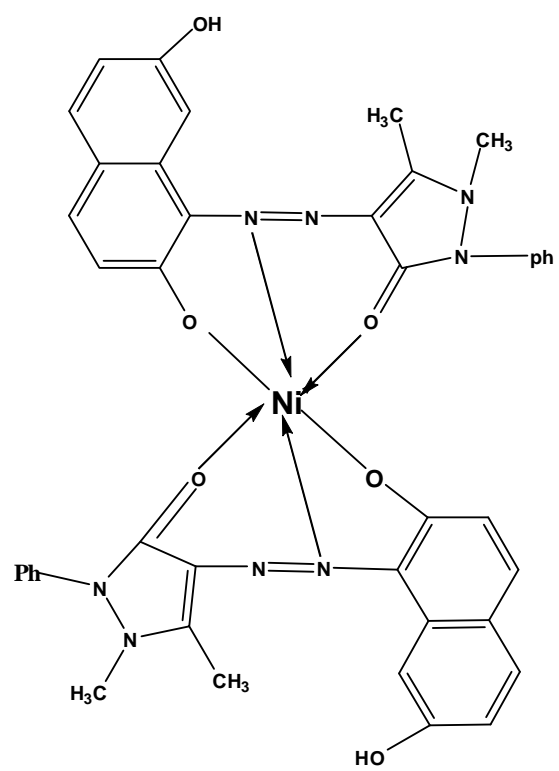

Structure of complex Ni(1-APANDOL $)_{2}$

Table 5. Determination of $\mathrm{Ni}(\mathrm{II})$ in synthetic samples

\begin{tabular}{|c|c|c|}
\hline Amount taken of $\mathrm{Ni}(\mathrm{II}) \mathrm{ppm}$ & Recovery\% & $\mathrm{RSD} \%$ \\
\hline 0.5 & 99.8 & 0.63 \\
\hline 1 & 99.9 & 4.0 \\
\hline
\end{tabular}

\section{Determination of nickel(II) in tea leaves samples}

$1 \mathrm{~g}$ of the powder of the tea leaves sample was taken in the crucible and heated on a hot plate about $30 \mathrm{~min}$. to near dryness in $250{ }^{\circ} \mathrm{C}$, it without frothing then heated strongly to $800-850{ }^{\circ} \mathrm{C}$ in furnace for $1 \mathrm{~h}$ after the moisture has been removed. We took utmost care avoid loss by sputtering. The ash was dissolved in the $2 \mathrm{~mL}$ of distilled water then added 10 $\mathrm{mL}$ of hydrochloric acid 1:1, after that heated the solution slowly until boiling, cooling to room temperature. After filtering the ash and transferred the filtrate volume into $25 \mathrm{~mL}$ volumetric flask and diluted with the same solvent, the solution becomes clear and transparent or a little green, the solution was left for $60 \mathrm{~min}$ and then ready for UV-Visible spectrophotometric analysis and atomic absorption ${ }^{22}$ (Table 6).

Table 6. Ni(II) levels $\left(\mu \mathrm{g} \cdot \mathrm{g}^{-1}\right)$ in tea leaves sample

\begin{tabular}{ccc}
\hline Ion in tea leave sample & $\begin{array}{c}\text { Amount found by our } \\
\text { Spectrophotometric method, } \mu \mathrm{g} \cdot \mathrm{g}^{-1}\end{array}$ & $\begin{array}{c}\text { Amount found by atomic } \\
\text { absorption method, } \mu \mathrm{g} . \mathrm{g}^{-1}\end{array}$ \\
\hline Liption yellow label tea & 1.34 & 1.16 \\
Liption clear green tea & 4.51 & 4.7 \\
\hline
\end{tabular}

\section{References}

1. Guha S, Lohar S, Hauli I, Mukhopadhyay S K and Das D, Talanta, 2011, 85 16581664.

2. Patal S, "The Chemistry of Hydrazo, Azo and Azoxy Group" Part I, Wiley, New York, 1975. 
3. Awad I M, J Chem Technol Biotechnol., 1992, 53(3), 227-236; DOI:10.1002/jctb.280530303

4. Zidan A S, El-Said A I, El-Meligy M S, Aly A A M and Mohammed O F, $J$ Therm Anal Calorim., 2000, 62, 665.

5. Awad I M A, Phosphorus Sulfur Silicon, 1996, 114, 17-28; DOI: $10.1080 / 10426509608046407$

6. Nielsen G D, Soderberg U, Jorgensen P J, Templeton D M, Rasmussen S N, Andersen K E and Grandjean P, Toxicol Appl Pharmacol., 1999, 154(1), 67-75; DOI:10.1006/taap.1998.8577

7. Anithe C, Sheela C D, Tharmaraj P and Raja S J, Spectrochim Acta Part A: Mole Biomole Spectro., 2012, 98, 35-42; DOI:10.1016/j.saa.2012.08.022

8. Aritake $\mathrm{Y}$ and Akitsu T, Polyhedron, 2012, 31(1), 278-284; DOI:10.1016/j.poly.2011.09.025

9. Gaber M, El-Hefnawy G B, El-Borai M A and Mohamed N F, J Therm Anal Calorim., 2012, 109, 1397-1405.

10. Abo El-Ghar M F, Abdel-Ghani N T, Badr Y and El-Borady O M, ISESCO Sci Tech Vision, 2007, 3(3), 58.

11. Santos V E O, Celante V G, Lelis M F F and Freitas M B J G, J Power Sources, 2012, 218, 435-444; DOI:10.1016/j.jpowsour.2012.07.024

12. Khazaeli S, Nezamabadi N, Rabani M and Panahi H A, Microchem J., 2013, 106, 147-153; DOI:10.1016/j.microc.2012.06.002

13. Turan S, Tokalioglu S, Şahan A and Soykan C, React Funct Polym., 2012, 72(10), 722-728; DOI:10.1016/j.reactfunctpolym.2012.07.002

14. Luo L, Chu B, Li Y, Xu T, Wang X, Yuan J, Sun J, Liu Y, Bo Y, Zhan X, Wang X, and Tang L, X-Ray Spectrom., 2012, 41(3), 133-143; DOI:10.1002/xrs.2364

15. Farukawa $\mathrm{M}$ and Shibata S, Anal Chim Acta, 1982, 140(1), 301-307; DOI:10.1016/S0003-2670(01)95476-5

16. Greenword N N and Earnshaw A, "Chemistry of the Elements" $2^{\text {nd }}$ Edition, Butterworth Heinemann, 1997.

17. Sheelam C D, Anitha C, Tharmaraj P and Kodimunthiri D, J Coord Chem., 2010, 63, 884-893; DOI:10.1080/00958971003660416

18. Li X, Wu Y, Gu D and Gan F, Dyes and Pigments, 2010, 86,182-189.

19. Pandey G and Narng K K, Synt Reas Inorg Metrog Chem., 2004, 34, 291.

20. Zaki Z M, Spectrochim Acta, 2000, 56(10), 1917-1923;

DOI:10.1016/S1386-1425(00)00249-3

21. Boryana D, Karima B, Elisaventa I and Freddy A, Canadian J Anal Sci., 2004, 49(6), 346-352.

22. Stasys T, Roland K and Aivaras K, CHEMIJA, 2004, 15(4), 49-52. 